\title{
KANDUNGAN KALSIUM PADA AIR SUMUR YANG DIKONSUMSI PARA PENDERITA PENYAKIT BATU GINJAL DI KECAMATAN RATATOTOK KABUPATEN MINAHASA TENGGARA
}

\author{
Oksfriani J. Sumampouw \\ Fakultas Kesehatan Masyarakat Universitas Sam Ratulangi Manado \\ Email: oksfriani82@yahoo.com
}

\begin{abstract}
Kidney stones affect $12 \%$ of the American population. Fifty percent (50\%) of people treated for kidney stones will have recurrences within 10 years. Calcium oxalate accounts for $90 \%$ of the kidney stone incidences. The soil structure of the Ratatotok area contains a lot of lime stone; therefore, the calcium content of well water there is estimated to be high. In fact many people in the South-East Minahasa region, particularly the Ratatotok District, use well water as a drinking water supply; therefore, they have a tendency to get kidney stones. This is an analytical explorative research using 25 respondents and the well water in Ratatotok. We used a descriptive exploratory method. In this research there were primary and secondary data. The primary data, the calcium content, were taken with a purposive method from the 25 wells used by the 25 kidney stone patients. The secondary data were taken from the 25 patients' questionnaires. The calcium content was analyzed in a laboratory by using a spectrophotometer. Respondents' characteristics were analyzed descriptively by using the SPSS version 16.0 for data counting. This research reported that 1) the majority of kidney stone patients in Ratatotok, South East Minahasa were male of 45-54 years old with an average age of 49.64 years, 2) all of the calcium contents of the well water consumed by the kidney stone patients at Ratatotok, South East Minahasa were higher than the maximum standard $(10 \mathrm{ppm})$. The conclusion of this research was that the well water consumed by the kidney stone patients in the Ratatotok District, South East Minahasa had a higher level of calcium than the maximum standard for it.
\end{abstract}

Keywords: Ratatotok, calcium content, well water, kidney stone

\begin{abstract}
Abstrak: Batu ginjal terjadi pada 12\% masyarakat Amerika. Lima puluh persen (50\%) dari penderita batu ginjal yang telah memperoleh pengobatan akan kembali mengalaminya dalam 10 tahun. Kalsium oksalat merupakan $90 \%$ penyebab insiden batu ginjal. Struktur tanah daerah Ratatotok banyak mengandung batu gamping atau kapur sehingga diperkirakan kandungan kapur dalam air sumur cukup tinggi. Masyarakat di Kecamatan Ratatotok Kabupaten Minahasa Tenggara banyak menggunakan air sumur sebagai sumber air minum sehingga berpeluang menderita batu ginjal. Metodologi yang digunakan ialah deskriptif eksploratif. Data yang diperoleh merupakan data primer dan sekunder. Data primer yaitu kadar kalsium diambil secara purposive pada 25 sumur yang digunakan oleh penderita batu ginjal dan data sekunder diperoleh dari 25 penderita batu ginjal yang telah didiagnosis menggunakan kuesioner. Kadar kalsium diukur menggunakan spektro-fotometer. Karakteristik responden diolah menggunakan SPSS versi 16.0. Dari penelitian ini diperoleh bahwa: 1) penderita batu ginjal di Ratatotok Minahasa Tenggara paling banyak berjenis kelamin laki-laki berumur 45-54 tahun dengan rata-rata umur 49,64 tahun, 2) Kandungan kalsium air sumur yang dikonsumsi oleh para penderita batu ginjal sudah berada di atas standar kualitas air minum. Kesimpulan dari penelitian ini yaitu air sumur yang dikonsumsi para penderita batu ginjal di Kecamatan Ratatotok Kabupaten Minahasa Tenggara mempunyai kadar kalsium di atas standar kualitas air minum.
\end{abstract}

Kata kunci: Ratatotok, kandungan kalsium, air sumur, batu ginjal 
Air bersih merupakan air yang kualitasnya memenuhi syarat kesehatan, yaitu syarat fisik, syarat bakteriologis, dan syarat kimia. Kualitas air bersih yang sehat bagi manusia sesuai dengan Permenkes RI No. 416/ MENKES/PER/IX/ 1990 dan Permenkes RI No. 907/MENKES/PER/ IX/2002 dibedakan atas tiga hal yaitu: syarat fisik air bersih tidak berwarna, tidak berasa, tidak berbau, jernih serta suhu air sebaiknya dibawah suhu udara. Syarat kimiawi air minum tidak tercemar oleh zat-zat kimia atau mineral yang melebihi standar yang ditetapkan. Syarat bakteriologis air minum tidak boleh mengandung bakteri penyakit. ${ }^{1}$

Salah satu penyakit yang disebabkan oleh konsumsi air yang tidak baik yaitu batu ginjal. Batu ginjal merupakan kumpulan kristal yang berasal dari mineral-mineral yang ada pada urine dan dikenal juga sebagai renal calculi. Beberapa penelitian yang telah dilakukan melaporkan bahwa penyakit ini disebabkan oleh beberapa hal seperti kalsium (kalsium oksalat), magnesium, ammonium, fosfat, asam uric, kalsium fosfat dan sistin. ${ }^{2}$

Ratatotok merupakan daerah pertambangan emas yang begitu terkenal di Sulawesi Utara. Geologi daerah Ratatotok didominasi batu gamping sebagai batuan pembentuk cekungan sedimen Ratatotok. Menurut Hakim dkk (1986) tanah merupakan sumber kalsium utama dan mengandung $3,6 \%$ kalsium. Batuan utama yang banyak mengandung kalsium yaitu kalsit $\left(\mathrm{CaCO}_{3}\right)$ dan dolomite $\mathrm{CaMg}\left(\mathrm{CO}_{3}\right)_{2}$, yang merupakan penyusun batuan sedimen limestone dan dolomit. Kadar mineral kalsium tanah rata-rata yaitu $0,4 \%$ pada lapisan tanah atas, sedangkan pada tanah-tanah organik kadarnya lebih tinggi yaitu dapat mencapai $2,8 \%$. $^{3}$ Tingginya kadar kalsium dalam tanah organik karena berasal dari air yang mengalir yang banyak membawa larutan didalamnya.

Berdasarkan hal tersebut maka penulis merasa tertarik untuk melakukan penelitian untuk menganalisis kandungan kalsium air sumur yang digunakan para penderita penyakit batu ginjal di Kecamatan Ratatotok
Kabupaten Minahasa Tenggara.

Penelitian ini bertujuan untuk mengetahui kandungan kalsium pada air sumur yang digunakan para penderita penyakit batu ginjal di Kecamatan Ratatotok Kabupaten Minahasa Tenggara.

\section{TINJAUAN PUSTAKA}

Kalsium merupakan zat kimia dengan simbol $\mathrm{Ca}$ dan nomor atom 20. Kalsium memiliki massa atom yaitu 40,078, berwarna abu-abu muda alkalin dan merupakan elemen kelima terbesar yang membentuk perut bumi. Kalsium juga menjadi ion kelima terbanyak yang terlarut pada air laut dengan molaritas dan massa setelah sodium, klorida, magnesium dan sulfat. ${ }^{4}$

Kalsium merupakan kebutuhan esensial bagi organisme hidup terutama pada fisiologi sel yaitu pada pergerakan ion $\mathrm{Ca}^{2+}$ kalsium masuk dan keluar sitoplasma berfungsi sebagai sebuah signal untuk banyak proses seluler. Selain itu, kalsium juga digunakan sebagai material utama pada tulang dan kerang. ${ }^{4}$

Kalsium oksalat dengan rumus kimia yaitu $\mathrm{CaC}_{2} \mathrm{O}_{4}$ atau $\mathrm{Ca}(\mathrm{COO})_{2}$ merupakan bahan kimia kristal yang kompleks berbentuk jarum. Sejumlah besar kalsium oksalat ditemukan di racun tanaman bisu cane (Dieffenbachia). Hal ini juga ditemukan dalam daun dari berbagai jenis Oxalis, Araceae, Taro, dan agaves, dan (dalam jumlah lebih rendah) terdapat pada bayam. Kristal kalsium oksalat tidak larut dalam air (nonsoluble) banyak ditemukan dalam batang tanaman, akar, dan daun. Kalsium oksalat juga merupakan komponen utama dari beerstone. Kalsium oksalat kristal dalam urine yang paling umum dapat menyebabkan batu ginjal. ${ }^{5}$

Standar kandungan kalsium pada air minum tidak banyak diperoleh acuannya. Standar kandungan Kalsium $(\mathrm{Ca})$ dalam air minum dalam Standar Nasional Indonesia (SNI) nomor 01-0220-1987 tentang air minum yaitu $10 \mathrm{mg} / \mathrm{L}$ (10 ppm). ${ }^{6}$

Batu Ginjal di dalam saluran kemih (kalkulus uriner) merupakan massa keras 
seperti batu yang terbentuk di sepanjang saluran kemih dan bisa menyebabkan nyeri, perdarahan, penyumbatan aliran kemih atau infeksi. Batu ini bisa terbentuk di dalam ginjal (batu ginjal) maupun di dalam kandung kemih (batu kandung kemih). Proses pembentukan batu ini disebut urolitiasis (litiasis renalis, nefrolitiasis). ${ }^{7}$

Batu bisa menyebabkan infeksi saluran kemih, jika batu menyumbat aliran kemih, bakteri akan terperangkap di dalam air kemih yang terkumpul diatas penyumbatan, sehingga terjadilah infeksi. Jika penyumbatan ini berlangsung lama, air kemih akan mengalir balik ke saluran di dalam ginjal, menyebabkan penekanan yang akan menggelembungkan ginjal (hidronefrosis) dan pada akhirnya bisa terjadi kerusakan ginjal. ${ }^{8}$

Obat diuretik thiazid (misalnya trichlormetazid) akan mengurangi pembentukan batu yang baru. Kadar oksalat yang tinggi dalam air kemih, yang menyokong terbentuknya batu kalsium, merupakan akibat dari mengkonsumsi makanan yang kaya oksalat (misalnya bayam, coklat, kacangkacangan, merica dan teh). Oleh karena itu sebaiknya asupan makanan tersebut dikurangi. ${ }^{9}$

\section{METODE PENELITIAN}

Penelitian ini dilaksanakan di Kecamatan Ratatotok Kabupaten Minahasa Tenggara pada bulan Nopember 2008-Februari 2009. Sampel yang digunakan yaitu 25 air sumur yang digunakan oleh para penderita batu ginjal. Penelitian ini merupakan penelitian deskriptif. Pengumpulan data dalam penelitian ini dengan metode wawancara melalui daftar pertanyaan dan pengukuran. Analisis data secara deskriptif dan hasilnya disajikan dalam bentuk tabel atau gambar.

\section{HASIL PENELITIAN}

Kandungan kalsium dalam air sumur terendah yaitu $15,08 \mathrm{mg} / \mathrm{L}$ dan tertinggi yaitu $52,64 \mathrm{mg} / \mathrm{L}$ dengan interval data 37,56. Nilai rata-rata untuk kandungan kalsium air sumur yaitu $31,10 \mathrm{mg} / \mathrm{L}$ dengan standar deviasi 14,60. Data ini menunjuk- kan bahwa dengan kandungan kalsium ratarata $52,64 \pm 14,60 \mathrm{mg} / \mathrm{L}$ yang dikonsumsi selama \pm 49,64 tahun atau asupan sebesar $15,08 \mathrm{mg} / \mathrm{L}$ selama 54 tahun dan asupan sebanyak 31,10 mg/L selama 42 tahun akan berpeluang terbentuk batu ginjal.

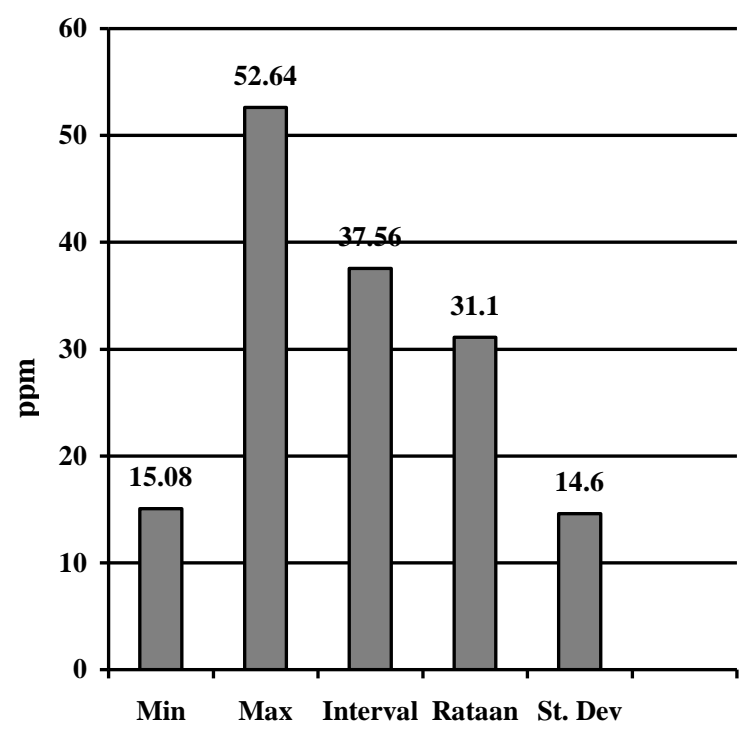

Gambar 1. Nilai kandungan kalsium dalam air sumur. Kesemuanya melewati standar kandungan kalsium $(\mathrm{Ca})$ dalam air minum sesuai dengan SNI nomor 01-0220-1987 tentang air minum, yaitu $10 \mathrm{mg} / \mathrm{L}(10 \mathrm{ppm})^{6}$

Kandungan kalsium dalam air sumur ini bisa disebabkan karena struktur tanah di Ratatotok yang banyak mengandung batuan berkalsium seperti batu gamping seperti penelitian yang dilakukan oleh Ta'in dan Sutrisno yang memperoleh hasil bahwa daerah Ratatotok struktur tanahnya didominasi oleh batu gamping. Keberadaan batu gamping ini menyebabkan terjadinya kontaminasi saat air dalam tanah, sehingga saat keluar melalui mata air di sumur air telah mengandung kalsium yang cukup tinggi. ${ }^{10}$

Hal ini diperkuat dengan pernyataan dari Foth yang mengatakan bahwa sebagian besar unsur kerak bumi berkombinasi dengan satu atau lebih lainnya untuk membentuk senyawa yang disebut mineral. Mineral-mineral tersebut pada umumnya terdapat dalam campuran untuk membentuk 
batuan bumi. Delapan unsur dalam kerak bumi yaitu oksigen $46,6 \%$, silikon $27,7 \%$, aluminium $8,1 \%$, besi $5,0 \%$ dan kalsium $3,6 \%$. Ada beberapa batuan yang mengandung kalsium yaitu horblende, augit, kalsit, dolomit, gypsum dan apatit. ${ }^{11}$

Asupan kalsium dalam tubuh manusia memang bisa meningkatkan resiko terjadinya batu ginjal, walaupun tidak diketahui besarnya paparan dan waktu yang dibutuhkan untuk terbentuknya batu ginjal. Penelitian yang dilakukan oleh Taylor, et al menunjukkan bahwa $80 \%$ penyakit batu ginjal disebabkan oleh asupan kalsium dan sebagian besar yaitu kalsium oksalat. ${ }^{12}$

Coe et al mengatakan bahwa sekitar $5 \%$ wanita dan $12 \%$ pria Amerika menderita batu ginjal dan prevalensinya akan meningkat dari tahun ke tahun. Sekitar $80 \%$ batu ginjal terbentuk dari kalsium oksalat dan kalsium fosfat, 10\% oleh struvit (magnesium amonium fosfat dan bakteri), $9 \%$ oleh asam uric dan $1 \%$ terbentuk dari sistin dan asam amonium. Terbentuknya batu ginjal dikatakan karena adanya suatu mekanisme pergantian fase yang tidak diinginkan di mana bahan-bahan ini berubah dari cairan menjadi padatan. ${ }^{13}$

Kalsium bisa menjadi penyebab terbentuknya batu ginjal, hal ini bisa dilihat melalui kandungan kalsium pada urine penderita. Penelitian ini dilakukan oleh Curhan et al yang mengevaluasi secara kimiawi urine penderita batu ginjal yang menemukan sebesar $\geq 200 \mathrm{mg} / \mathrm{L}$ kalsium ditemukan pada urine penderita batu ginjal. ${ }^{14}$

Najem et al dalam penelitiannya tentang kejadian-kejadian tertekan dalam kehidupan dan resiko gejala batu ginjal mengatakan bahwa batu ginjal disebabkan oleh kalsium, protein, garam, oksalat dan fosfat. Selain itu, hal ini disebabkan juga karena rendahnya konsumsi cairan, sitrat, magnesium, fiber dan alkohol. ${ }^{15}$

Harus diakui bahwa terjadinya batu ginjal bukan hanya karena faktor asupan kal-sium saja tetapi disebabkan oleh banyak faktor seperti asupan fosfat, cairan, fiber dan sebagainya. Selain itu, perilaku hidup, umur, riwayat penyakit orang tua dan berat badan juga berpengaruh pada terjadinya batu ginjal.

Penelitian dari Taylor et al mengatakan bahwa obesitas dan penambahan berat badan akan meningkatkan resiko terbentuknya batu ginjal dan besarnya lebih tinggi pada wanita daripada pria. Selanjutnya Taylor et al mengatakan bahwa berdasarkan penelitian yang mereka lakukan terhadap 1437 responden dengan gejala batu ginjal menemukan bahwa asupan kalsium dan pembentukan batu ginjal tidaklah berhubungan pada responden yang telah berumur 60 tahun atau lebih. Selain itu, ditemukan bahwa konsumsi protein hewani berhubungan dengan resiko batu ginjal khususnya pada pria deng-an indeks massa tubuh $<25 \mathrm{~kg} / \mathrm{m}^{2}$. Sodium, fosfor, sukrosa, fitate, vitamin B, vitamin D dan kalsium suplemen tidak berdiri sendiri berhubungan dengan resiko batu ginjal, sehingga disimpulkan bahwa hubungan antara asupan kalsium dan terbentuknya batu ginjal bervariasi pada setiap tingkatan umur. $^{12,16}$

Leonetti et al melakukan penelitian di Perancis tentang perbandingan karakteristik penderita batu ginjal kalsium dengan orang sehat mengatakan bahwa 12-15\% penduduk Amerika dan 2 per 1000 orang Perancis menderita batu ginjal. Sekitar 75$80 \%$ pria penderita batu ginjal disebabkan oleh kalsium dan 70-80\% dari penderita batu ginjal kalsium disebabkan oleh kalsium oksalat. Dalam kesimpulan penelitian ini dikatakan bahwa kombinasi dari jalur genetika (riwayat penyakit batu ginjal keluarga dan berat badan yang berlebihan) dan faktor gizi (asupan kalsium per hari yang rendah, tingginya kandungan kalsium dan oksalat yang keluar dari tubuh melalui urine) berhubungan dengan terbentuknya batu ginjal. ${ }^{17}$

Heller mengatakan bahwa asupan kalsium secara bertahap akan meningkatkan pembentukan batu ginjal, walaupun dalam kesimpulannya ia mengatakan bahwa dalam populasi normal asupan kalsium yang baik disarankan dilakukan karena akan menurunkan prevalensi kerapuhan tulang namun perlu adanya peningkatan konsumsi cairan, pembantasan konsumsi garam, oksalat dan 
daging hewan. ${ }^{18}$

Penelitian lain yang dilakukan oleh Curhan et al mengatakan bahwa konsumsi vitamin B6 dalam jumlah yang besar akan mengurangi resiko pembentukan batu ginjal pada wanita. Pembatasan rutin konsumsi vitamin $\mathrm{C}$ untuk mencegah pembentukan batu ginjal tidak bisa dijamin dalam penelitian ini. Selanjutnya Najem, et al mengatakan bahwa pembentukan batu ginjal berhubungan dengan stress yang dialami oleh masyarakat. Curhan, et al melakukan penelitian untuk melihat hubungan antara ukuran tubuh dengan resiko terkena batu ginjal mem-peroleh hasil yaitu berat badan berhubungan secara terbalik dengan prevalensi batu ginjal tapi tidak berhubungan dengan insiden pembentukan batu ginjal. Hasil penelitian ini juga menemukan bahwa ukuran tubuh berhubungan dengan resiko terbentuknya batu ginjal dan besarnya resiko bervariasi berdasarkan jenis kelamin. ${ }^{19,15,20}$

Curhan et al dalam penelitiannya tentang hubungan riwayat penyakit keluarga dan resiko batu ginjal menemukan bahwa riwayat penyakit batu ginjal keluarga secara mendasar dapat meningkatkan resiko pembentukan batu ginjal. Data penelitian ini juga menjelaskan bahwa pembantasan konsumsi kalsium dapat meningkatkan resiko pembentukan batu ginjal walaupun secara individu memiliki riwayat penyakit batu ginjal dari keluarga. ${ }^{21}$

Curhan et al melakukan penelitian tentang hubungan minuman dan resiko batu ginjal pada wanita yang dilakukan terhadap 81.093 wanita pada pusat studi kesehatan perawat sejak tahun 1986-1990 menemukan bahwa peningkatan dalam konsumsi cairan akan dapat mengurangi resiko batu ginjal. Selain itu, pemilihan jenis minuman juga akan sangat bermanfaat. ${ }^{22}$

Namun, hal ini berbeda dengan penelitian yang dilakukan oleh Curhan et al dan Curhan et al yang melakukan penelitian tentang perbandingan konsumsi kalsium dengan kalsium tambahan dan nutrisinutrisi lainnya sebagai faktor-faktor penyebab resiko batu ginjal pada wanita serta faktor-faktor makanan dan resiko insiden batu ginjal pada wanita muda yang menga- takan bahwa asupan yang tinggi dari konsumsi kalsium dilakukan untuk mengurangi resiko gejala batu ginjal, walaupun konsumsi makanan tambahan yang berkalsium akan meningkatkan resiko. Hal ini disebabkan oleh mengkonsumsi kalsium mengurangi absorpsi atau penyerapan oksalat. Selain itu, beberapa makanan faktor resiko batu ginjal bervariasi dampaknya berdasarkan umur dan jenis kelamin. ${ }^{23,24}$

Menurut Candra, standar-standar air minum yang harus dipenuhi agar suatu persediaan air dapat dinyatakan layak dikonsumsi yaitu memenuhi persyaratan fisik, biologis, zat-zat kimia dan radioaktif. Negara-negara yang maju lebih menekankan standar kimia, sedangkan negara berkembang lebih menekankan pada standar biologis. Kalsium dalam International Standar of Drinking Water dari World Health Organization (WHO) dikelompokkan sebagai bahan-bahan yang mempengaruhi portabilitas air bersama-sama dengan besi, mangan, tembaga, zink, sulfat, magnesium, klorida dan lainnya. Batasan maksimal yang diperbolehkan yaitu $10 \mathrm{mg} / \mathrm{L}$ (10 ppm). ${ }^{25,6}$ Berdasarkan standar ini maka seluruh air yang diuji telah melewati standar yang ada.

\section{KESIMPULAN}

Berdasarkan hasil analisis data menunjukkan bahwa kandungan kalsium pada air sumur yang dikonsumsi oleh para penderita batu ginjal di Kecamatan Ratatotok Kabupaten Minahasa Tenggara sudah berada di atas standar kualitas air minum.

\section{DAFTAR PUSTAKA}

1. Departemen Kesehatan RI. Peraturan Menteri Kesehatan RI Nomor: 907/ Menkes/SK/VII/2002 Tentang Syarat dan Pengawasan Kualitas Air. Jakarta, 2002.

2. Kidney stone. [Homepage on the internet]. 2008a. Available from http://en. Wikipedia.org/wiki/kidney stone. September 30th 2008

3. Hakim N, Nyakpa Y, Lubis AM, Nugroho SG, Diha A, Hong GB dkk. Dasar-dasar ilmu tanah. Universitas Lampung, 1986.

4. Donatelle RJ. Health, The Basics. 6th ed. 
San Francisco (USA): Pearson Education Inc, 2005.

5. Dana J. "Removing Beerstone". Modern Brewery Age. Birko Corporation R\&D, 1998.

6. Standar Nasional Indonesia nomor 01-02201987 tentang Air Minum. Jakarta: Departemen Perindustrian; 1987.

7. Chiras DD. Human biology. Jones and Bartlett Publisher, 2007.

8. Moe OW. Kidney stones: Pathophysiology and medical management. The Lancet. 2006; 367(9507): 333-344.

9. Goldfarb, Coe S, Fredric L. Prevention of recurrent nephrolithiasis. American Family Physician. 1999; 60(8): 2269-76.

10.Ta'in Z, Sutrisno. Pemantauan dan evaluasi konservasi sumber daya mineral di daerah Belang, kabupaten Minahasa, propinsi Sulawesi Utara. subdit konservasi. Kolokium Hasil Kegiatan Inventarisasi Sumber Daya Mineral. 2003; 4: 1-13.

11.Foth HD. Dasar-dasar ilmu tanah. Edisi keenam. Alih bahasa oleh Soenartono Adisoemarto. Jakarta: Erlangga, 1994.

12.Taylor EN, Stampfer MJ, Curhan GC. Obesity, weight gain, and the risk of kidney stones. Journal of the American Medical Association. 2005; 293(4): 455462.

13. Coe FL, Evan A, Worcester E. Kidney stone disease. Journal of Clinical Investigation. 2005; 115(10): 2598-2608.

14.Curhan GC, Willet WC, Speizer FE, Stampfer MJ. Twenty-four-hour urine chemistries and the risk of kidney stones among women and men. Journal of Kidney International. 2001; 59(2): 22902298.

15.Najem GR, Seebode JJ, Samady AJ, Feuerman M, Friedman L. Stressful life events and risks of symptomatic kidney stones. Journal of Epidemiology. 1997; 26(5): 1017-1025.

16. Taylor EN, Stampfer MJ, Curhan GC. Dietary factors and the risk of incident kidney stones in men: New insights after 14 Years of follow-up. Journal of the
American Society of Nephrology. 2004; 15(3): 3225-3232.

17.Leonetti F, Dussol B, Berthezene P, Thirion $\mathbf{X}$, Berland $\mathbf{Y}$. Dietary and urinary risk factors for stones idiopathic calcium stones formers compared with healthy subjects. Journal of Nephrology Dialysis Transplantation. 1998; 13(7): 617-622.

18.Heller JH. The Role of calcium in the prevention of kidney stones. Journal of the American College of Nutrition. 1999; 18(5): 3731-3739.

19.Curhan GC, Willet WC, Speizer FE, Stampfer MJ. Intake of vitamins B6 and $\mathrm{C}$ the risk of kidney stones in women. Journal of Kidney International. 1999; 59(2): 2290-2298.

20.Curhan GC, Willet WC, Speizer FE, Stampfer MJ. Body Size and Risk of Kidney Stones. Journal of the American Society of Nephrology. 1998; 9(2): 16451652.

21.Curhan GC, Willet WC, Speizer FE, Stampfer MJ. Family history and risk of kidney stones. Journal of the American Society of Nephrology. 1997; 8(4): 15681573.

22.Curhan GC, Willet WC, Speizer FE, Stampfer MJ. Beverage use and risk for kidney stones in women. Journal of the American Society of Nephrology. 1998; 128(7): 434-540.

23.Curhan GC, Willet WC, Knight EL, Stampfer MJ. Dietary factors and the risk of incident kidney stones in younger women. Journal of Arch Intern Medicine. 2004; 164(8): 885-891.

24.Curhan GC, Willet WC, Speizer FE, Stampfer MJ. Comparison of dietary calcium with supplemental calcium and other nutrients as factors affecting the risk of kidney stones in women. Journal of the American Society of Nephrology. 1997; 126(7): 497-504.

25.Candra B. Pengantar kesehatan lingkungan. Penerbit Buku Kedokteran EGC, 2007; Hal. 39-74. 